\title{
Day Times Picomole Per Liter Per Milligram Per Gram Per Day
}

National Cancer Institute

\section{Source}

National Cancer Institute. Day Times Picomole Per Liter Per Milligram Per Gram Per Day.

NCI Thesaurus. Code C117911.

Day times picomole per liter, divided by milligram per gram per day. 